\title{
Intergenerational solidarity in family influencing factors
}

\author{
Nadezda Kuligina $^{1, *}$ and Signe Dobelniece ${ }^{2}$ \\ ${ }^{1}$ Riga Stradins University, Riga, Latvia \\ ${ }^{2}$ Latvia University of Life Sciences and Technologies, Jelgava, Latvia
}

\begin{abstract}
The purpose of this study was to investigate gender differences of adult children in manifestations of emotional closeness and its influence on frequency of contacts with their parents, as well as impact of the socio-economic status of parents on manifesting solidarity by the adult child. The participants of the research were 410 adult children, aged 18-62, living in Latvia, and with at least one parent alive. The results of the research showed that significant differences exist in manifestations of emotional closeness and frequency of contacts with parents by gender of a child and the socio-economic status of parents. Adult daughters more often meet and contact their parents than sons do. Emotional closeness and frequency of contacts correlate with providing functional help to their parents. Normative obligations of adult children to show care and provide help to their parents have been stipulated by the legislation of Latvia; however, the results of the research showed that parents who are emotionally close to their children received significantly greater help and support.
\end{abstract}

Key words - intergenerational solidarity, emotional closeness, family relations.

\section{Introduction}

Strengthening of intergenerational solidarity in family is a priority direction of development in Latvia within the nearest decade, taking into consideration the background of economic and social processes taking place on national and global scale [1]. The ageing of the population, increased life expectancy, decreased birth rate, emancipation, and migration prove to be a challenge to the generation of adult children as they pursue the realization of their capabilities and maintain the cultural traditions of their families related to care and help provided to the parents. Normative obligations that have been established by the legislation [2] stipulate that children should take care for their parents and help them; however, intergenerational solidarity in family includes other social interactions with parents which facilitate the strengthening of the family solidarity and motivate the adult children to provide help to their parents.

The theoretical approach to researching the intergenerational solidarity in family was suggested by Bengtson and Roberts in 1991, and it not only allows for enhanced examination of the internal processes within the family, but also for studies of these processes in depth.

Studies on intergenerational solidarity in family have gained much popularity in various countries with a broad range of cultural and historical family traditions across Europe and the

\footnotetext{
*Corresponding author: nadezda.kuligina@ rsu.edu.lv
} 
world. For example, the Longitudinal Study of Generations (USA), the Netherlands Kinship Panel Study (The Netherlands), the Norwegian Life-Course Generations and Gender Study (Norway), Panel Analysis of Intimate Relationships and Family Dynamics (Germany) [3] and Survey of Health, Ageing and Retirement in Europe (28 European countries and Israel).

Research on intergenerational solidarity in family was focused on two factors: gender of adult children, and socio-economic status of their parents. The research allows for creation of a new view on social processes taking place in Latvia in relation to strengthening intergenerational solidarity in family.

The aim of the paper is to study such impact factors of intergenerational solidarity in the family. The paper focuses mainly on the adult child's gender, communication frequency and emotional closeness of an adult child and a parent.

\section{Theoretical framework of intergenerational solidarity in family}

The concept of intergenerational solidarity has mostly spread through studies conducted in the Northern America dealing with relationships between generations in relation to ageing of the society and increase in number of older people, as well as with changes to the family structure that take place due to socio-demographic and socio-economic global processes.

Intergenerational solidarity is defined as social cohesion between generations or intergenerational cohesion between parents and children once the children grow up and create their own families [4].

Theory of intergenerational solidarity was developed in 1991 by sociologists and psychologists Bengtson and Roberts. The mentioned model was empirically tested, and later, in 1994, it was supplemented and was used as a model construction to study intergenerational solidarity in family [5]. Intergenerational relationships are understood as any form of exchange between generations, six dimensions of exchange or "solidarity" are distinguished: structural, associative, affective, consensual, normative, and functional [4]. The structural solidarity refers to the opportunity structure, which determines the specific realization of family interactions. Typical measurements are geographical distance and residential proximity; but availability of kin, parents, children and siblings, as well as their age, sex, marital status, health status and working arrangements are seen as important factors of structural solidarity. The associative dimension refers to the amount and kind of intergenerational contact, either face-to-face or by phone, e-mail or any other means. Therefore, frequency and intensity of contact can be distinguished. The affective dimension comprises emotional closeness as well as conflict as measures of the quality of the relationship between children and their parents. The consensual dimension measures the amount of agreement in values and beliefs - whatever the specific content of these convictions may be. The normative dimension refers to the extent of commitment to filial and parental obligations by the respective members of intergenerational relationships. The functional dimension measures all kinds of financial, instrumental and emotional support, exchanged between parents and children [4]. When researching intergenerational solidarity in family, most scholars emphasise one or several dimensional expressions of intergenerational solidarity with a purpose to identify the influencing factors and threats, as well as manifestations that might affect the interaction between adult children and their parents [7].

Analysis of previous studies show that researchers focus on various factors that have impact on the family solidarity: gender difference is widely studied in the context of intergenerational solidarity in family [8], especially relevant is research related to providing help and care [9], emotional closeness or affect [10] and contact frequency [11].

Research shows that daughters are more responsive to the needs of their parents than sons are and respond differently to the same resources. The authors have provided three arguments 
to explain the reasons: parents are more likely to be able to rely on their daughters than on their sons because 1) daughters are in a better position to provide care, since regular support requires substantial discretionary time. Men are involved in the labour force much more often and work longer hours on average than women. Gender differences in intergenerational care are often explained by the different employment patterns among adult children; 2) women are more responsive to the needs of their parents and to provide more regular and time-intensive care than sons; 3 ) is put forward in theoretical research on welfare states and family cultures [12].

While conducting a more enhanced examination of types of interaction between adult children and their parents, it is necessary to note that cultural traditions of families in the area of help and care provided to parents are formed depending on the region where the family lives. Sociologist D. S. Reher described that families living in Northern Europe, as well as the United States of America historically have formed traditions that after reaching the age of majority the children leave the homes of their parents and set up their personal lives. Normative obligations of adult children to care for their parents are significantly weaker than in the countries of Southern Europe and Mediterranean Region where children continue to live with their parents until the moment when they form their own families, or even longer. At the same time, a high-level social aid provided by the government can be seen in such countries with weaker normative solidarity, and parents receive help and care while living in social homes for retired people. Meanwhile, parents in the countries of the Mediterranean region believe that it is normal to support their children not only while raising them, but also after the children have established their own families [13]. Researchers Reher D., Requena Miguel, 2018., point out that stringent family obligations which are established throughout many generations still affect changes in the approach taken by the government when ensuring the general welfare, and it forms a part of the social policy [14]. In Estonia, compulsory intergenerational family solidarity shaping choices between work and care, perceptions of informal female carers and local policymakers was examined, encompassing the Baltic States [15].

The family obligations form one of the reasons for intergenerational interaction. However, Albert and Ferring hold a view that strong family values can only partially influence provision of functional help between an adult child and a parent; and a child may act on standards and norms accepted by the society [16]. It is important to pay attention to the family obligations because these point towards the actual functioning of the family. Strong family norms influence the exchange of instrumental support, and mutuality in relationships is an important support factor. The greater the responsibility of parents and children, the more support is received by the parent. Authors Ikkink et al. showed that mothers, parents in old age and requiring support, as well as parents without a partner received a rather significant support from their adult children [17].

Norms are generally accepted rules of behaviour of which some refer to family relationships. For example, researcher Kalmijn notes two aspects: firstly, the family obligations within family that determine the necessity to take care of the parents, especially when in need. Secondly, mutuality norm exists in relationships between children and parents, stipulating that it is necessary to return what was received before [18]. The mentioned norm of the intergenerational relationships in family provides children with an opportunity to provide care and attention as well as material help in return for what parents have given to their children when the children were small, were attending school, and grew up. Several of these aspects are addressed in this study. 


\section{Research method and sample}

Data were obtained from survey to research the manifestations of intergenerational solidarity in family and its impact factors, which was designed during the period from June 2019 to January 2020. Web-survey method was used to collect empirical data. The survey sampled 410 persons, corresponded to the selection criterion of the research and participated in the empirical part of the research. The criterion was as follows: residents of Latvia who had at least one living parent.

To describe obtained results, we used - for quantitative variables such central tendency indicators as mean (M) with dispersion indicator standard deviation (SD). Pearson's chisquared test was used to assess if there is an association between variables. Pearson's rank correlation coefficient (rs) was used to find trends between two variables.

The questionnaire was based on the Bengtson's and Roberts' model of intergenerational solidarity in the family.

The sample $(n=410)$ consists of $81 \%$ women and $19 \%$ men aged 18 to 62 years, Me $=$ 31 years $(\mathrm{SD}=11$. $)$. More than a half are married or living with a partner, however, about one in three is single. This is understandable when looking at the age structure of the respondents where younger individuals dominate (almost $3 / 4$ are up to 39 years old).

More than a half of the respondents $-60 \%$ - have a child /children; and $88 \%$ have a sister or brother. The respondents are quite well off by their self-assessment: $12 \%$ rate their current financial situation as very good, $39 \%$ as good, $44 \%$ as average, only $4 \%$ as bad, and $0.5 \%$ as very bad. The fact that every fifth respondent lives with the parent in the same household certainly has a role to play in mutual relations, and effects the functional solidarity in the family.

$71 \%$ of respondents have both parents alive. In that case, one had to be chosen for whom information would be provided. As a result, $87 \%$ of respondents chose the mother and $13 \%$ the father. About $1 / 3$ of the sample has retired parents but the majority - $65 \%$ - provided answers about the parent which had not reached the age of retirement (it was 63 years and 6 months in 2019 and 63 years and 9 months in 2020).

Health condition of economically active parents or non-retired was described as good by $50 \%$ of respondents, but health condition of the economically inactive or retired parents was marked as good for $32 \%$ of respondents.

It should be noted that the sample is not representative. The composition of the sample has an impact on the results obtained and limits the degree of generalization.

\section{Results}

By using the multidimensional model of intergenerational solidarity in family, the following results were obtained:

Geographical proximity: The results show that $19 \%$ of respondents live with their parents in the same house/apartment; $12 \%$ of these respondents are aged 18 to 29 . Twenty $\%$ of respondents stated that they need up to 10 minutes to get to their parents' home; $18 \%$ need from 10 to 30 minutes; $11 \%$ need 30 minutes to 1 hour; $15 \%$ would require from 1 to 3 hours; and $17 \%$ of respondents would need 3 hours and more. A significant difference exists between men and women: $\chi^{2}=12.577 ; r=0.028$, women need less time than men do to get to their parent's home.

Associations: women meet their parents more often than men: $\chi^{2}=15.875 ; r=0.014$, $(r<0.05)$; women contacted their parent by phone more frequently than men $\chi^{2}=40.911$; $r<0.001$; other information technologies $-\chi^{2}=17.883 ; r=0.007$. 
Functional solidarity, or help and support from the adult child to their parent, shows that there is no significant difference between an adult son and an adult daughter in terms of providing help at home (cleaning home, doing laundry, making a meal, personal hygiene, etc.) $-\chi^{2}=0.272 ; r=0.602$; outside home (help with transport, shopping together, visits to doctors, help in the garden, etc.) $-\chi^{2}=0.036 ; r=0.849$ and financial aid $-\chi^{2}=1.943 ; r=$ 0.163 . The results of research showed that our expectations that adult daughters will provide more functional help to their parents than sons were not proven. We assume that even though a distance to the parent's home and frequent contacts with parents are positive factors for providing aid to parents yet would not be exclusive; and in further studies more attention should be paid to the fact whether the adult children have their own children, as well as the marital status and employment of women.

The second part of the research will cover manifestations of emotional closeness of adult daughters and sons towards their parent, and impact of normative beliefs in family on frequency of contacts with a parent and providing help to the parent. The scale of emotional solidarity including relationships of affection, closeness, understanding, trust, and respect (see Table 1).

Table 1. Difference of emotional solidarity expression between a daughter and a son.

\begin{tabular}{|l|l|l|}
\hline \multicolumn{1}{|c|}{ Emotional solidarity expressions } & $\begin{array}{l}\text { Value } \\
\left(\chi^{2}\right)\end{array}$ & $\begin{array}{l}\text { Asymptotic } \\
\text { Significance } \\
\text { (p) }\end{array}$ \\
\hline $\begin{array}{l}\text { 1. There is a great understanding between me and my mother } \\
\text { / father }\end{array}$ & 8.195 & 0.085 \\
\hline $\begin{array}{l}\text { 2. I and my mother/father have very close and friendly rela- } \\
\text { tionships }\end{array}$ & 8.205 & 0.084 \\
\hline 3. I have an emotionally close link with my mother / father & 2.175 & 0.704 \\
\hline $\begin{array}{l}\text { 4. I entrust my secrets and personal experiences to my mother } \\
\text { / father }\end{array}$ & 31.901 & $<0.001$ \\
\hline $\begin{array}{l}\text { 5. I receive as much from my mother / father emotionally as I } \\
\text { give back to them }\end{array}$ & 7.981 & 0.092 \\
\hline $\begin{array}{l}\text { 6. My attitude towards my mother / father is based on mutual } \\
\text { respect }\end{array}$ & 1.948 & 0.745 \\
\hline 7. Me and my mother / father have strong family relations & 8.937 & 0.063 \\
\hline $\begin{array}{l}\text { 8. Me and my mother / father have many common interests } \\
\text { (hobbies, leisure activities) }\end{array}$ & 22.159 & $<0.001$ \\
\hline $\begin{array}{l}\text { 9. It is always interesting to spend time with my mother / } \\
\text { father }\end{array}$ & 25.631 & $<0.001$ \\
\hline
\end{tabular}

The obtained results showed that there are significant differences between daughters and sons in trusting their secrets and personal experiences to their parent significant differences can also be observed in common interests between an adult child and parent when spending time together $\left(\chi^{2}=22.159 ; p<0.001\right.$ and $\left.\chi^{2}=25.631 ; p<0.001\right)$.

When examining provision of help, such types of help as help with household chores, help outside home, and financial help provided by adult children to their parent were included, as well as the analysis of functional help; help received by adult children from their parents include help with household chores, help outside home, financial help and help in childcare.

Gender of the adult child and socio-economic status of their parent affect expression of intergenerational solidarity in family; but first of all, expression of intergenerational solidarity 
in family was verified in all dimensions by calculating the mean value M (Mean) and SD (Standard Deviation) for all respondents $N=410$ (see Table 2).

Table 2. Mean value and standard deviation $(N=410)$.

\begin{tabular}{|c|c|c|c|}
\hline & Mean & SD & Range \\
\hline Geography. Prox. Contact & 4.395 & 0.221 & 1 min.- 6 max. \\
\hline Affect & 3.947 & 0.16 & 1 min. -5 max. \\
\hline Help provided & 0.586 & 0.01 & 0 - no, $1-$ yes \\
\hline Help received & 0.457 & 0.07 & 0 - no, $1-$ yes \\
\hline Family norm & 4.29 & 0.08 & 1 min. -5 max. \\
\hline
\end{tabular}

The obtained results showed that help provided by children exceeds the scope of help received from parents $M=0.586,(\mathrm{SD}=0.01)$ and $M=0.457$, $(\mathrm{SD}=0.07)$. Adult children also showed strong emotional ties with their parent $M=3.947$, $(\mathrm{SD}=0.16)$, and adherence to strong family beliefs $M=4.29$, (SD $=0.08)$.

The next step was used to verify whether there are differences in manifesting of intergenerational solidarity in family between an adult son and adult daughter in all dimensions, and the results are as follows Table 3.

Table 3. Differences in manifestations of intergenerational solidarity between daughters and sons.

\begin{tabular}{|c|l|l|l|l|l|}
\hline & $\begin{array}{l}\text { Sum of } \\
\text { Squares }\end{array}$ & df & $\begin{array}{l}\text { Mean } \\
\text { Square }\end{array}$ & F & $\begin{array}{l}\text { Sig. } \\
\text { (p) }\end{array}$ \\
\hline $\begin{array}{l}\text { Geographical prox. } \\
\text { Contact (Solidarity S) }\end{array}$ & 2.772 & 4 & 0.693 & 4.648 & $\mathbf{. 0 0 1}$ \\
\hline Affect & 9.844 & 9 & 1.094 & 8.206 & $\mathbf{. 0 0 0}$ \\
\hline Help provided & 0.365 & 3 & 0.122 & 0.787 & $\mathbf{. 5 0 1}$ \\
\hline Help received & 3.551 & 4 & 0.888 & 6.031 & $\mathbf{. 0 0 0}$ \\
\hline Family Norms & 2.841 & 7 & 0.406 & 2.705 & $\mathbf{. 0 0 9}$ \\
\hline
\end{tabular}

Binary Logistic Regression analysis was conducted to examine manifestations of intergenerational solidarity between adult children depending on the gender of the adult child; and assumptions were confirmed that adult daughters and frequency of contacts: $p<0.001$, emotional closeness with parents: $p<0.001$, and strong normative family beliefs: $p=0.009$. The results showed that there are significant differences between daughters and sons in receiving help from parents: $p<0.001$, adult daughters receive more help from their parents than sons do. Thus, is confirmed a relation to differences in manifestation of intergenerational solidarity in family between an adult child and parent depending on the child's gender.

Next, hypothesis was verified that the social status of a parent affects intergenerational solidarity in family. It is assumed that depending on their age, employment and on the fact whether they have their own children the adult children would alienate from their parents and that it would be reflected on manifestations of intergenerational solidarity in family (Table 3).

The results of research show that regarding manifestation between a non-retired parent and a retired parent significant differences exist in such aspects as contact with parents, emotional closeness, providing and receiving help, $p<0.001$. However, the beliefs of adult children in relation to family norms do not change depending on the parent's social status (between a non-retired parent and a retired parent) $-p=0.100(p>0.05)$, and children maintain their normative beliefs in family norms during a long period of life.

When researching intergenerational solidarity in family between an adult child and their parent, hypothesis was verified of whether adult children more often contact their parents and 
Table 4. Differences in manifestations of solidarity between non-retired and retired parents.

\begin{tabular}{|c|l|l|l|c|l|}
\hline & $\begin{array}{l}\text { Sum of df } \\
\text { Squares }\end{array}$ & $\begin{array}{l}\text { Mean } \\
\text { Square }\end{array}$ & F & $\begin{array}{l}\text { Sig. } \\
(\mathbf{p})\end{array}$ \\
\hline $\begin{array}{l}\text { Geographical prox. } \\
\text { Contact (Solidarity S) }\end{array}$ & 7.572 & 4 & 1.893 & 8.93 & $\mathbf{. 0 0 0}$ \\
\hline Affect & 7.203 & 9 & 0.8 & 3.713 & $\mathbf{. 0 0 0}$ \\
\hline Help provided & 10.363 & 3 & 3.454 & 16.885 & $\mathbf{. 0 0 0}$ \\
\hline Help received & 9.803 & 4 & 2.451 & 11.869 & $\mathbf{. 0 0 0}$ \\
\hline Family Norms & 2.732 & 7 & 0.39 & 1.73 & $\mathbf{. 1 0 0}$ \\
\hline
\end{tabular}

provide more help if emotional closeness exists between the adult child and their parent, (see Table 5).

Table 5. Analysis of correlations of manifestations of intergenerational solidarity in family (bivariate correlation two-tailed).

\begin{tabular}{|c|c|c|c|c|c|c|}
\hline & & $\begin{array}{l}\text { Solidarity } \\
\text { S }\end{array}$ & $\begin{array}{l}\text { Solidarity } \\
\text { Affect }\end{array}$ & $\begin{array}{l}\text { Help pro- } \\
\text { vided }\end{array}$ & $\begin{array}{l}\text { Help re- } \\
\text { ceived }\end{array}$ & Norms \\
\hline \multirow{2}{*}{$\begin{array}{l}\text { Geographical } \\
\text { prox. + Contact } \\
\text { (Solidarity S) }\end{array}$} & Pearson & 1 & $.975^{*}$ & $.968 *$ & 0.914 & 0.487 \\
\hline & Sig. (2-tailed) & & 0.025 & 0.032 & 0.086 & 0.513 \\
\hline \multirow{2}{*}{$\begin{array}{l}\text { Solidarity } \\
\text { Affect }\end{array}$} & Pearson & & 1 & $.999 * *$ & 0.802 & 0.669 \\
\hline & Sig. (2-tailed) & & & 0.001 & 0.198 & 0.331 \\
\hline \multirow[t]{2}{*}{ Help provided } & $\begin{array}{l}\text { Pearson } \\
\text { Correlation }\end{array}$ & & & 1 & 0.784 & 0.691 \\
\hline & Sig. (2-tailed) & & & & 0.216 & 0.309 \\
\hline \multirow[t]{2}{*}{ Help received } & $\begin{array}{l}\text { Pearson } \\
\text { Correlation }\end{array}$ & & & & 1 & 0.092 \\
\hline & Sig. (2-tailed) & & & & & 0.908 \\
\hline
\end{tabular}

* Correlation is significant at the 0.05 level (2-tailed).

** Correlation is significant at the 0.01 level (2-tailed).

Results of the correlation analysis showed that emotional closeness between an adult child and their parent correlate with the frequency of contacts $\left(\mathrm{r}_{\mathrm{s}}=0.975, p=0.025\right)$ and help provided to the parent $\left(r_{\mathrm{s}}=0.968, p=0.032\right)$. The received result confirmed the assumption that adult children more frequently maintain communication with their parent and provide more help to their parent if a strong emotional affection exists in their family. Strong family norms do not correlate with providing help: $p=0.309$, and do not correlate with the frequency of contacts between an adult child and a parent: $p=0.513$. International studies show that emotional solidarity between generations and instrumental solidarity do not correlate, and a negative link is shown [19], children provide help to their parents even when there is no emotional closeness; however, our results showed that strong emotional closeness stimulates adult children to contact and help their parents. 


\section{Conclusions}

1. Basing on the model of intergenerational solidarity in family, which was proposed by Roberts and Bengtson in 1991, the following manifestations of solidarity were examined: structural solidarity and frequency of contacts; emotional closeness; and family norms, specifically focusing on two groups of respondents: adult daughters and sons, as well as paying attention to parents with various socio-economic statuses.

2. By the examined example, it was shown that women manifest a greater emotional closeness with their parent, and they contact their parents more often.

3. Even though obtained results do not show differences between children in providing help, yet daughters receive more support from their parents.

4. It should also be noted that frequency of contacts, provision and receipt of help, and emotional closeness with parents is affected by the parent's socio-economic status, namely, whether the parent is of working age or retired.

5. The results of research showed that frequency of contacts, functional help, and emotional closeness are not constant, and when the parent reaches a different socio-economic status or retires, the ageing parents are under the greater risk of becoming lonely.

6. The hypothesis was confirmed that manifestation of intergenerational solidarity in family between adult children and their parents might change throughout life as shown by the example, when researching the socio-economic status of parents.

7. The results also confirmed the assumption that an adult child communicates with their parent more frequently and helps more frequently in case of strong emotional ties with their parent. The shown example proved that strong family norms do not influence provision of help and frequency of contacts.

8. It is necessary to continue research of intergenerational solidarity in family between adult children and their parents by making further use of representative selection of adult children in Latvia, as well as research the intergenerational solidarity in family among respondents of older age who due to their health condition might need help from their adult children.

\section{References}

[1] Pārresoru koordinācijas centrs, "Latvijas nacionalīis attīstības plāns 2021. 2027. gadam" (2020). Available: https://www.pkc.gov.lv/sites/default/ files/inlinefiles/20200204_NAP_2021_2027_gala_redakcija_projekts_.pdf

[2] L. Government, "The Constitution of the Republic of Latvia," pp. 1-9 (2002)

[3] A. Steinbach, "Intergenerational relations across the life course," Adv. Life Course Res. 17(3), pp. 93-99 (2012). DOI:10.1016/j.alcr.2012.06.002

[4] B. Nauck, T. Steinbach, and A. Steinbach, "Intergenerational Relationships," (SSRN Electron. J., no. January 2018) (2011). DOI:10.2139/ssrn.1462084

[5] A. Steinbach, "Explaining the Frequency of Contact between Generations in Germany," p. 23 (2007) [Online]. Available: https://www.researchgate.net/publication/254981438

[6] B. Nauck, T. Steinbach, and A. Steinbach, "Intergenerational Relationships," (SSRN Electron. J., Dec. 2011). DOI: 10.2139/ssrn.1462084

[7] M.J.A. Hogerbrugge and A.E. Komter, "Solidarity and ambivalence: Comparing two perspectives on intergenerational relations using longitudinal panel data," Journals Gerontol. - Ser. B Psychol. Sci. Soc. Sci. 67 B(3), pp. 372-383 (2012) DOI:10.1093/geronb/gbr157

[8] S.O. Daatland, K. Herlofson, and I.A. Lima, "Balancing generations: On the strength and character of family norms in the West and East of Europe," Ageing Soc. 31(7), pp. 1159-1179 (Oct. 2011) DOI:10.1017/S0144686X10001315 
[9] C. Saraceno and W. Keck, "Can we identify intergenerational policy regimes in Europe?” Eur. Soc. 12(5), pp. 675-696 (2010) DOI:10.1080/14616696.2010.483006

[10] E.M. Merz et al., "There is more to receiving than needing: theoretical arguments and empirical explorations of crowding in and crowding out," JOURNALS Gerontol. Ser. BPSYCHOLOGICAL Sci. Soc. Sci. 19(2), pp. 729-751 (2011) DOI:10.1159/000342211

[11] M. Silverstein et al., "Factors That Predispose Middle-Aged Sons and Daughters to Provide Social Support to Older Parents," J. Marriage Fam. 57(2), p. 465 (1995) DOI:10.2307/353699

[12] K. Haberkern, T. Schmid, and M. Szydlik, "Gender differences in intergenerational care in European welfare states," Ageing Soc. 35(2), pp. 298-320 (2015) DOI:10.1017/S0144686X13000639

[13] D. S. Reher, "Family Ties in Western Europe: Persistent Contrasts," Popul. Dev. Rev. 24(2), p. 203 (1998) DOI:10.2307/2807972

[14] D. Reher and M. Requena, "Living Alone in Later Life: A Global Perspective," Popul. Dev. Rev. 44(3), pp. 427-454 (2018) DOI:10.1111/padr.12149

[15] H. Tarum and D. Kutsar, "Compulsory intergenerational family solidarity shaping choices between work and care: Perceptions of informal female carers and local policymakers in Estonia," Int. J. Soc. Welf. 27(1), pp. 40-51 (2018) DOI:10.1111/ijsw.12272

[16] I. Albert and D. Ferring, "Intergenerational solidarity in adulthood: The role of family norms in intergenerational support and ambivalence |Medugeneracijska solidarnost $\mathrm{u}$ odrasloj dobi: Uloga obiteljskih normi u medugeneracijskoj potpori i ambivalentnosti," Drus. Istraz. 27(1), pp. 5-25 (2018) DOI:10.5559/di.27.1.01

[17] J. Gierveld, J. Véron, S. Pennec, and J. Légaré, "Demographic Change and the Social Contract of Informal Support Within the Family," pp. 177-190 (2007)

[18] M. Kalmijn, "Family solidarity in the Netherlands," Popul. Stud. (NY) (2007) [Online]. Available: https://www.researchgate.net/publication/241884013

[19] M. Silverstein, D. Gans, A. Lowenstein, R. Giarrusso, and V.L. Bengtson, "Older Parent-Child Relationships in Six Developed Nations," J. Marriage Fam. 72(4), pp. 1006-1021 (2010) 